\title{
MEDIA DAN WACANA: TELAAH KETERBUKAAN INFORMASI PUBLIK DI PROVINSI JAWA BARAT
}

\author{
Dedi Kurnia Syah Putra \\ Universitas Telkom Bandung \\ dedikurniasp@telkomuniversity.ac.id
}

\begin{abstract}
The relation of interest between Pikiran Rakyat (HUPR) and West Java Provincial Government (West Java Provincial Government), especially in the case of public information disclosure, became an important focus in this research. Through the discourse study formulated by Teun A. Van Dijk, this research seeks to reveal how the HUPR plays a role in the production of news discourse. Then, the issue of this discourse is seen from Gramsci's assumption of hegemony. Some of the findings lead to a pattern of mutual interest, both HUPR and West Java Provincial Government. The interest is in the form of image and reputation related to information disclosure on the side of the power of government, and the economic side of the circulation of advertising suppliers in HUPR by the Government from the side of HUPR. Of course, the interest, established because of the pull of power in producing information that later in the consumption by the public on a permassive basis. Furthermore, these conditions resulted in the finding that the greatest cooptation was successfully carried out by the Government, while the HUPR had no significant power in drafting its own discourse, as it had been systematically dictated by the Government, both economically, politically and socially. This research confirms that HUPR does not perform its function as sharing information as knowledge, but only as a medium or a tool of government power in creating legitimacy of reputation as an open government. Gramsci through the theory of Hegemony (1991) believes that the government will use all resources to preserve its power. And that power was conseptualized by Van Dijk through the construction of media discourse. With this assumption, then what is happening between HUPR and the government is a mutual attraction of interests related to power in each corridor. Media with the interests of capital, and the government with the interests of reputation and image.
\end{abstract}

Keywords: Hegemony of Discourse, Media Relations and Politics, Information Disclosure West Java.

\section{PENDAHULUAN}

Bergulirnya reformasi ditandai dengan adanya tuntutan tata kelola kepemerintahan yang baik (Good Governance). Demi terwujudnya tata kelola yang baik tersebut, negara melalui pilar legislatif, menyusun satu ketentuan hukum yang merangkum kebutuhan akuntabilitas, transparansi dan partisipasi masyarakat dalam setiap proses terjadinya kebijakan publik.
Terlebih lagi dengan revolusi teknologi komunikasi yang mencuat awal tahun 1990, modernisasi teknologi informasi dan komunikasi memberikan keleluasaan bagi masyarakat untuk mendapatkan informasi yang mereka inginkan dengan mudah dan cepat.

Dengan keadaan tersebut, pemerintah dituntut untuk membuka diri kepada masyarakat dalam memberikan infomasi-informasi dan kebijakan-kebijakan yang sangat diperlukan serta mudah diakses dari mana saja. 
Terlebih dengan adanya Undang-undang (UU) Nomor 14 Tahun 2008 tentang Keterbukaan Informasi Publik (KIP), pemerintah diamanatkan untuk membuka informasi terkait penyelenggaraan pemerintahan kepada masyarakat seluasluasnya dan semudah-mudahnya akses. Hanya saja, kebebasan akses atas informasi yang kian kini tak berbatas mempunyai resiko yang juga tidak sedikit. Beberapa di antaranya adalah kuatnya kontrol warga negara atas kinerja pemerintah, sehingga sangat mungkin akan mengganggu stabilitas kinerja itu sendiri karena ruang kontrol yang terlalu mendominasi.

Menurut UU KIP, yang dimaksud dengan informasi publik adalah informasi yang dihasilkan, disimpan, dikelola, dikirim, dan atau diterima oleh suatu badan publik yang berkaitan dengan penyelenggara dan penyelenggaraan negara dan atau penyelenggara dan penyelenggaraan badan publik lainnya yang sesuai dengan UU KIP ini serta informasi lain yang berkaitan dengan kepentingan publik. Dengan adanya amanat UU KIP maka seluruh instansi pemerintah baik pemerintah pusat dan pemerintah daerah (Provinsi Dan Kabupaten atau Kota) diwajibkan untuk memberikan informasi kepada masyarakat melalui media penyebaran informasi terkecuali jenis informasi yang mendapatkan pengecualian oleh undangundang.

Penyediaan informasi oleh badan publik pemerintah dilaksanakan oleh Pejabat Pengelola Informasi dan Dokumentasi (PPID).
Pejabat PPID bertanggung jawab pada penyimpanan, pendokumentasian, penyedian, dan/atau pelayanan informasi. Agar keterbukaan informasi publik berjalan sebagaimana mestinya, maka dibentuklah Komisi Informasi. Komisi Informasi ini juga merupakan pelaksanaan lanjutan terkait UU KIP. Komisi ini bertugas untuk menyelesaikan sengketa informasi publik melalui mediasi dan/atau ajudikasi nonlitigasi disamping berfungsi menjalankan undang-undang dan peraturan pelaksanaannya.

Keterbukaan informasi memberi peluang bagi rakyat untuk berpartisipasi dalam berbagai kebijakan publik. Kondisi ini sekaligus dapat mendorong terciptanya clean and good governance karena pemerintah dan badanbadan publik dituntut untuk menyediakan informasi yang lengkap mengenai apa yang dikerjakannya secara terbuka, transparan dan akuntabel. Mengenai mekanisme untuk mendapatkan informasi dapat dibaca pada artikal Mekanisme Keterbukaan Informasi Publik. Kebebasan informasi diharapkan menjadi spirit demokratisasi yang menawarkan kebebasan sekaligus tanggung jawab secara bersamaan. Kebebasan informasi, di satu sisi harus mendorong akses publik terhadap informasi secara luas. Sementara di sisi yang lain, kebebasan informasi juga sekaligus dapat membantu memberikan pilihan langkah yang jelas bagi pemerintah dalam mengambil suatu kebijakan secara strategis. 
Pelayanan publik atau sering disebut pelayanan masyarakat, pelayanan umum atau juga public service merupakan salah satu kegiatan dari pemerintah yang selalu menjadi perhatian publik. Opini publik terhadap aktivitas pemerintahan dalam bidang pelayanan masyarakat yang beredar dan berkembang masih memiliki kecenderungan yang lemah ketimbang keunggulan yang dapat diwujudkan secara konkrit. Kelemahan ini tercermin dari banyaknya keluhan terhadap terjadinya penyimpangan baik biaya, prosedur, atau ketidakpastian waktu untuk suatu jasa yang diinginkan. Banyaknya keluhan yang disampaikan melalui berbagai media massa, baik cetak maupun elektronik adalah bukti tidak efektifnya pelayanan publik yang diberikan oleh para aparatur pemerintah, yang sesungguhnya dapat diakomodir menjadi nilai plus.

Rendahnya kualitas pelayanan birokrasi di Indonesia terjadi di semua organisasi atau birokrasi pemerintahan sebagaimana juga sering dimuat dan diliput dalam berbagai media massa. Kecenderungan tersebut terjadi baik di tingkat pusat maupun di daerah, termasuk pada birokrasi di lingkungan pemerintahan Provinsi Jawa Barat.

Penelitian ini dimaksudkan untuk mengungkap lebih jauh praktik kuasa media massa dalam membangun wacana, dengan pendekatan hegemoni Gramsci, khususnya tentang praktik kuasa yang bekerja dibalik wacana informasi publik di Provinsi Jawa Barat.
Tujuannya, mengkaji wacana media dalam hubungannya dengan kekuasaan dan kepentingan yang mengitarinya dalam konteks praktik keterbukaan informasi publik di Provinsi Jawa Barat. Juga, sebagai upaya mengungkap bagaimana cara-cara yang digunakan antarkelas kepentingan tersebut menanamkan kepentingannya kepada media massa.

Persoalan krusial dalam penelitian ini, adalah adanya pertarungan kepentingan antara Harian Umum Pikiran Rakyat (HUPR) dan Pemerintah Provinsi Jawa Barat (Pemprov Jabar), khususnya dalam hal keterbukaan informasi publik. Di sini, peneliti tertarik untuk lebih lanjut mengemukaan persoalan tersebut, pertarungan kepentingan yang melandasi bangun realitas berbeda di antara kedua isntitusi publik di atas.

HUPR, dalam khazanah kajian media dan komunikasi merupakan institusi publik yang tidak kalah penting sebagaimana adanya pemerintahan. Untuk itu, sudah seharusnya kedua institusi ini berjalan seimbang dan beriring, pemerintah berfungsi sebagai penggerak roda pemerintahan, sedang media menjadi mesin pengetahuan bagi masyarakat.

Hanya saja yang terjadi kemudian, tidaklah demikian. Media massa memiliki alur yang berbeda dengan pemerintahan, meskipun membawa nama kepentingan bersama, media massa cenderung berkuasa membangun wacana yang tidak melibatkan kepentingan publik arti luas. 
Juga, pemerintah memiliki agenda yang seringkali tidak terkait langsusng dengan kepentingan publik, justru kepentingan yang kental kekuasaan sepihak. Di sinilah persoalan penelitian ini menarik, adanya tarik ulur, pertarungan ideologi yang melibatkan publik sebagai objeknya.

Membaca realitas sementara tersebut, peneliti mencoba menggunakan sudut pandang Antonio Gramsci dalam menguraik persoalan ini ke depan. Gramsci, merupakan tokoh eksponen Marxian dengan teori dan pandangan hegemoni dan revolusi sosial. Gramsci mematahkan tesis utama Marxisme bahwa dominasi kekuasaan tidak selamanya berakar pada kepentingan ekonomi saja, akan tetapi juga berakar juga pada kebudayaan dan politis (pragmatis sosial). Dalam struktur kekuasaan, bagi Gramsci setidaknya melibatkan dua hal untuk membangun kuasa. Pertama, relasi kuasa melalui alur kesadaran, kondisi ini dapat dipenetrasikan dengan jalan pemaksaan dan kekerasan; Kedua, penguatan kekuasaan melalui alur hegemoni, yaitu dengan cara kepatuhan dan kesadaran pada tiap-tiap elemen masyarakat.

\section{METODE PENELITIAN}

Penelitian ini menggunakan metode analisis wacana kritis yang dikembangkan oleh Teun A van Dijk dari paradigma kritis dengan pendekatan kualitatif. Konsep Critical Discourse Analysis (CDA) adalah "lebih mementingkan aspek kualitatif dari daripada kuantitatif".
CDA menekankan perhatiannya pada pemaknaan teks ketimbang panjumlahan unit kategori seperti dalam analisis isi.

Dasar dari Critical Discourse Analysis (CDA) adalah interpretatif yang mengandalkan interpretasi dan penafsiran peneliti. Sementara analisis isi kuantitatif, pada umumnya hanya dapat digunakan untuk membedah muatan teks komunikasi yang bersifat manifest (nyata), sedangkan CDA justru berpretensi memfokuskan pada pesan laten (tersembunyi).

Sementara itu penelitian kualitatif juga tidak mengandalkan bukti berdasarkan logika matematis, prinsip angka atau metode statistik. Penelitian kualitatif bertujuan untuk mempertahankan bentuk dan isi perilaku manusia dan menganalisis kualitas-kualitasnya, alih-alih mengubah menjadi entitas-entitas kuantitatif.

Analisis Wacana Kritis dari van Dijk mengidentifikasi tiga konstruksi utama, yaitu; dimensi teks, kognisi sosial dan konteks sosial. Inti analisis wacana adalah menggabungkan ketiga demensi wacana tersebut ke dalam satu kesatuan. van Dijk (1997: 144) mengemukakan bahwa "CDA digunakan untuk menganalisis wacana-wacana kritis, diantaranya politik, ras, gender, kelas sosial, hegemoni, dan lain-lain”.

Setelah data terkumpul dan dikelompokkan sesuai dengan tujuan penelitian untuk dianalisis dan diberikan interprestasi dengan cara mengklasifikasikannya dengan kerangka teori, lalu kemudian di simpulkan. 
Dengan demikian, setelah diperoleh wacana yang akan dianalisis, maka sebagai rujukan adalah dengan menggunakan analisis wacana kritis seperti yang dikemukakan Teun Van Dijk. Oleh van Dijk wacana kemudian digambarkan memiliki tiga elemen, yaitu : dimensi teks, kognisi sosial, dan konteks sosial.

Pertama, dalam dimensi teks, terdiri dari ; a) struktur makro, yaitu makna global dari suatu teks yang dapat diamati dari topik atau tema yang diangkat suatu teks, elemennya adalah tematik; b) Super Struktur, yaitu kerangka suatu teks, seperti bagian pendahuluan, isi, penutup, dan kesimpulan. Elemennya adalah skematik; c) Struktur Mikro, yaitu makna lokal dari suatu teks yang dapat diamati dari pilihan kata, kalimat, dan gaya yang dipakai suatu teks. Kedua, yaitu kognisi sosial yaitu bagaimana wartwan atau penulis mengetahui dan memahami peristiwa yang ditulisnya. Ketiga, konteks sosial, yaitu mengetahui apa yang sedang terjadi di masyarakat, dan dampak di masyarakat setelah adanya pemeberitaan tersebut.

Inti analisis wacana adalah menggabungkan ketiga demensi wacana tersebut ke dalam satu kesatuan. Teknik analisis wacana model van Dijk di pilih karena menganalisis ketiganya (dimensi teks, kognisi sosial dan konteks sosial). Teknik ini dirasa cocok dibandingkan dengan analisis wacana (discourse analysis) lainnya yang lebih mengarah pada ideologi.

\section{PEMBAHASAN}

Terdapat beberapa isu yang erat kaitannya dengan kepentingan publik di Harian Umum Pikiran Rakyat. Berikut matriknya:

Tabel 1. Matrik Berita Isu Kepentingan Publik di Harian Umum Pikiran Rakyat

\begin{tabular}{|c|c|c|c|}
\hline No. & Judul & SU & Edisi \\
\hline 1 & $\begin{array}{l}\text { Hindari } \\
\text { Penyimpangan, } \\
\text { BPK Perketat } \\
\text { Pengawasan } \\
\text { Dana Desa }\end{array}$ & $\begin{array}{l}\text { Pemerintah melakukan pengawasan atas } \\
\text { alokasi dana yang sudah disalurkan ke } \\
\text { desa-desa penerima dana hibah di } \\
\text { kabupaten Sukabumi. Langkah tersebut } \\
\text { setelah digelontorkan bantuan kepada } \\
381 \text { desa se-Kabupaten Sukabumi. } \\
\text { Bantuan untuk alokasi dana desa maupun } \\
\text { dana desa dengan kisaran Rp } 700 \text { juta } \\
\text { hingga Rp } 1 \text { miliar setiap desa } \\
\text { dikhawatirkan bermasalah dalam } \\
\text { pengelolaan sehingga tidak bisa } \\
\text { dipertanggung-jawabkannnya. }\end{array}$ & $\begin{array}{l}\text { Minggu, } 30 \\
\text { Oktober } 2016\end{array}$ \\
\hline 2 & $\begin{array}{l}\text { Inspektorat } \\
\text { Diminta Awasi } \\
\text { Pungli }\end{array}$ & $\begin{array}{l}\text { Bupati Sumedang Eka Setiawan } \\
\text { mengintruksikan kepada kantor } \\
\text { Inspektorat Kabupaten Sumedang untuk } \\
\text { memantau sekaligus mengawasi } \\
\text { kemungkinan terjadinya praktik pungutan } \\
\text { liar (pungli) di dinas dan Satuan Kerja } \\
\text { Perangkat Daerah (SKPD) lainnya di } \\
\text { lingkungan Pemkab Sumedang. Salah } \\
\text { satu isntitusi yang disorot adalah dinas } \\
\text { pendidikan, di mana pendidikan } \\
\text { merupakan institusi yang paling dekat } \\
\text { dengan publik, karena melibatkan } \\
\text { masyarakat secaralangsung. }\end{array}$ & $\begin{array}{l}\text { Rabu, } 2 \\
\text { November } \\
2016\end{array}$ \\
\hline 3 & $\begin{array}{l}\text { Wali Kota } \\
\text { Siapkan Perwal } \\
\text { UMK } 2017\end{array}$ & $\begin{array}{l}\text { Pemerintah Kota Bekasi menjanjikan akan } \\
\text { memfasilitasi aspirasi kaum buruh terkait } \\
\text { penetapan Upah Minimum Kota Bekasi } \\
\text { tahun 2017. Pada dasarnya Pemkot } \\
\text { Bekasi berkeinginan menyejahterakan } \\
\text { buruh. Akan tetapi, tentunya upaya } \\
\text { tersebut tetap harus sesuai dengan } \\
\text { peraturan yang berlaku di atasnya. } \\
\text { Peraturan tersebut mengatur penetapan } \\
\text { UMK yang mengacu pada kondisi } \\
\text { ekonomi di suatu daerah. Laju inflasi } \\
\text { menjadi pertimbangan utamanya. } \\
\text { Menurut PP Nomor Tahun 78, rumus } \\
\text { penetapan UMK ialah UMK tahun berjalan } \\
\text { ditambah dengan hasil kali laju inflasi } \\
\text { dengan besar UMK tahun berjalan. } \\
\text { Dengan demikian, penetapan UMK tidak } \\
\text { lagi melalui rapat Dewan Pengupahan } \\
\text { Kota yang didahului dengan survei harga } \\
\text { di pasar demi penentuan angka } \\
\text { Kebutuhan Hidup Layak. }\end{array}$ & \begin{tabular}{|l} 
Selasa, 25 \\
Oktober 2016
\end{tabular} \\
\hline 4 & $\begin{array}{l}\text { Pejabat } \\
\text { Disnakertrans } \\
\text { Tertangkap } \\
\text { Tangan Terkait } \\
\text { Rekrutmen }\end{array}$ & $\begin{array}{l}\text { Pemerintah melalui Wakil Bupati } \\
\text { Karawang Jimmy Ahmad Zamakhsyari, } \\
\text { turut bersama Komisi D DPRD Kabupaten } \\
\text { Karawang menangkap tangan adanya } \\
\text { praktik rekrutmen tenaga kerja di kawasan } \\
\text { industri Karawang. Dalam sidak tersebut, } \\
\text { didapati Kepala Bidang Penempatan } \\
\text { Tenaga Kerja Dinas Ketenagakerjaan dan } \\
\text { Transmigrasi Karawang sedang } \\
\text { melakukan pertemuan. Melihat keadaan } \\
\text { yang demikian, Wakil Bupati meminta } \\
\text { dinas terkait untuk mengevaluasi kinerja } \\
\text { aparaturnya demi tegaknya perundang- } \\
\text { undangan yang melarang seorang pejabat } \\
\text { publik melakukan lobi-lobi. Terutama jika } \\
\text { menyangkut profesionalisme pekerjaan. } \\
\text { Meskipun demikian, seorang aparat } \\
\text { pemerintahan tersebut menolak jika } \\
\text { dirinya disebut melakukan lobi-lobi terkait } \\
\text { rekruitasitenaga kerja. }\end{array}$ & $\begin{array}{l}10 \text { Oktober } \\
2016\end{array}$ \\
\hline
\end{tabular}




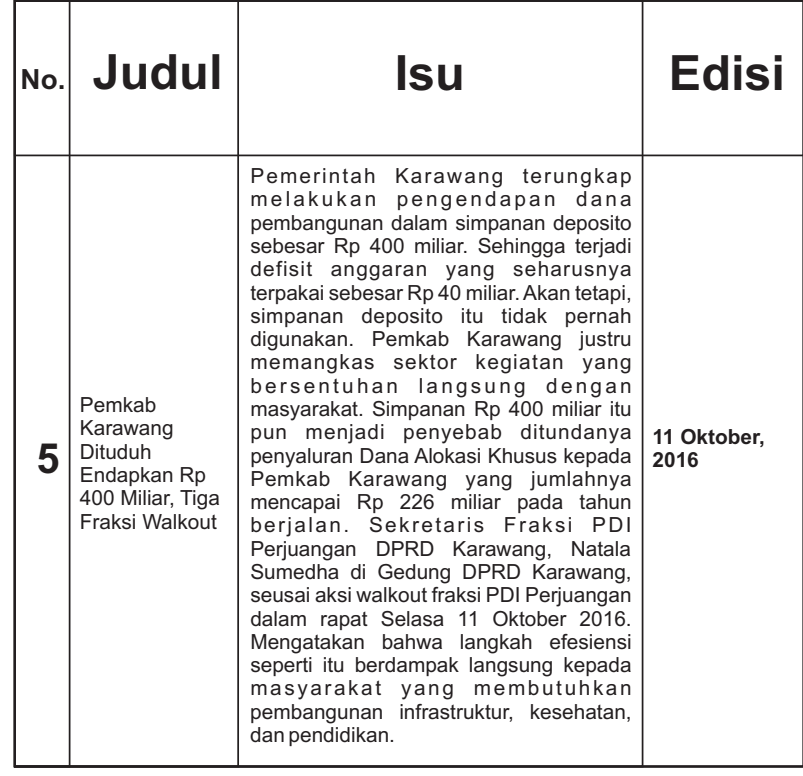

Secara terbuka, Harian Umum Pikiran Rakyat (HUPR) tidak menonjolkan wacana apapun dalam pemberitaannya. Hanya saja penelitian ini menemukan beberapa fakta menarik terkait dengan posisi tawar HUPR dalam membangun pesan keterbukaan informasi bagi Provinsi Jawa Barat. Membedah keterbukaan informasi yang diharapkan oleh HUPR. Keterbukaan informasi publik merupakan segala bentuk materi pesan yang terkait kepentingan publik yang dikelola oleh pemerintah provinsi Jawa Barat.

Dalam hal ini, HUPR berposisi sebagai kontributor sekaligus produsen informasi tersebut untuk publik. Secara umum, bagian ini mengungkap bagaimana HUPR memandang keterbukaan informasi di Jawa Barat selama ini, juga perihal bagaimana dan apa yang telah dilakukan HUPR, melalui pemberitaanya, juga melalui penguatan pengetahuan SDM (Jurnalis) dalam memproduksi berita agar pemberitaan tersebut bermanfaat bagi masyarakat.
Masalah keterbukaan informasi publik yang sangat penting adalah merumuskan mana informasi yang boleh dibuka ke publik dan mana yang tidak. Selain itu, Undang-undang Keterbukaan Informasi Publik sebagai salah satu wujud konkret dari proses demokratisasi di indonesia. Di mana transparansi atas setiap informasi publik membuat masyarakat dapat ikut berpartisipasi aktif dalam mengontrol setiap langkah dan kebijakan yang diambil oleh pemerintah, sehingga penyelenggaraan kekuasaan dalam negara demokrasi dapat dipertanggungjawabkan kembali kepada rakyat.

Akuntabilitas dapat membawa ke tata pemerintahan yang baik, yang bermuara pada jaminan terhadap hak asasi manusia dan mencerdaskan kehidupan bangsa. Untuk itu, bangunan wacana keterbukaan informasi publik yang digali dalam penelitian ini merupakan informasi yang seutuhnya menjadi kebutuhan masyarakat. Di atas, setidaknya beberapa kategori pemberitaan yang muncul dan mewakili keterbukaan informasi, berbasis kebutuhan masyarakat berkaitan dengan hukum, politik, birokrasi, dan lainnya.

Selama ini, persolan terkait keterbukaan informasi ini lebih banyak persoalan anggaran, sedang isu lain yang berkaitan secara langsug kepada masyarakat, semisal alur pembuatan KTP, penggunaan anggaran pembangunan, pengawasan atas infrastruktur dan lain-lain tidak begitu didengar. Kondisi ini terjadi karena dua hal, masyarakat yang memang tidak memerlukan informasi tersebut, dan pemerintah yang tidak menyediakan fasilitas aksesnya. 
Sehingga keterbukaan informasi masih dalam tahap apa yang ditanyakan, belum sampai pada keaktifan pemerintah memberikan informasi secara terbuka.

Rana Akbari Fitriawan (42), Komisioner Komisi Informasi Publik (KIP) Provinsi Jawa Barat, mengatakan masih banyak SKPD yang belum memahami mana informasi yang boleh dibuka ke publik dan mana yang tidak. Terlebih soal anggaran, tidak mungkin disampaikan secara detail, cukup rumusan kebijakan anggaran dan program-programnya. Keterbukaan informasi adalah bagian dari harmoni, dengan tetap memiliki keterbatasan yang jelas. Sehingga, Informasi yang lancar akan mengurangi masalah, sebaliknya bila terhambat dapat menyebabkan masalah sampai pada kekerasan.

Hanya saja, kondisi tersebut tidak sejalan dengan kerja media massa di Jawa Barat, HUPR lebih menekankan pada aksesnya, bukan konten informasinya. Yang mana untuk mengakses konten sangat rumit dan terbatas, terutama di daerah luar Kota Bandung sebagai Ibukota Jawa Barat. Selama ini akses informasi melalui Dinas Kominfo Jabar. Hanya saja, kondisi tersebut hanya berupa alur birokrasi saja, sedangkan ketersediaan konten informasinya masih sangat minim. Sehingga, HUPR kesulitan memberikan informasi yang lengkap kepada masyarakat terkaitkepentingannya.
"Keterbukaan informasi bagi kami di komisioner adalah segala bentuk materi pesan birokrasi yang seharusnya dbuka di publik. Di buka itu artinya pemerintah menyediakan fasilitas aksesnya, bukan menunggu masyarakat mencari tahu baru pemerintah sibuk mencari materi informasi" (Rana Akbari Fitriawan, Komisioner Komisi Informasi Publik Jabar)

Lebih jauh, Rana mengungkapkan bahwa keterlibatan media massa di Jawa Barat, terutama HUPR selama ini tidak dominan dan menekan. HUPR hanya menjadi media pengirim kabar, tanpa adanya upaya untuk memposisikan diri sebagai penekan pemerintah sehingga pemerintah tergerak untuk inisiatif menyediakan layanan informasi kepada masyarakat. juga, Rana mengklaim kemungkinan adanya daya tawar HUPR kenapa tidak melakukan penekanan terhadap pemrintah. Sedang Komisioner sifatnya haya sebagai pengawas.

"Tentu yang memeiliki wewenang kan pemerintah, kami di KIP hanya sebatas pengawas saja, pemberi rekomendasi, sedang tapuk keputusan ada di gedung sate (pemerintah). Dan HUPR, seharusnya berpern aktif dalam hal-hal seperti ini (keterbukaan informasi)." (Rana Akbari Fitriawan, Komisioner Komisi Informasi Publik Jabar)

Sedang pimpinan redaksi HUPR, Islaminur Pempasa memberikan keterangan pendukung. 
Bahwa akses informasi sejatinya teah berada di satu pintu, yaitu Dinas Komunikasi dan Informatika (Diskominfo), dinas inilah yang dianggap sebagai juru bicara pemerintah, pusat informasi publik berada. Dan pemrintah secara representatif telah di wakili oleh Diskominfo.

"Memang betul ada regulasi yang menyatakan segala akses informasi publik melalui Diskominfo Jabar. Hanya saja, mereka (Diskominfo) tidak menyediakan informasinya. Misal kita memerlukan penjelasan tentang penggunaan dana desa, atau alur pembuatan KTP, mereka akan melemparkan ke dinas-dinas terkait, sehingga informasi yang benar-benar diperlukan tidak tersedia dalam satu pintu itu”. (Islaminur Pempasa, Pimred HUPR)

Dalam memahami sebuah teks, kognisi sosial menjadi hal terpenting. Pada umumnya teks diasumsikan tidak mempunyai makna namun anggapan ini tidak sepenuhnya benar, karena teks tersebut sesungguhnya diberikan makna oleh si pemakai bahasa (pewarta). Makna inilah yang dikonstruksi oleh pewarta. Seperti yang dijelaskan Teun van Dijk, bahwa dalam memahami suatu teks perlu ada penelitian mengenai kognisi sosial; kesadaran mental penulis yang membentuk teks tersebut.

Untuk mendukung kognisi sosial, peneliti menggunakan metoda penggalian data dengan melakukan serangkaian interview terhadap
Jurnalis HUPR. Selain itu, dalam penelitian ini juga dibutuhkan satu pendekatan atas representasi kognisi dan strategi wacana keterbukaan informasi yang dilakukan oleh HUPR dalam memproduksi suatu teks. Berita keterbukaan informasi yang dipublikasikan melalui HUPR di kolom berita. Mereka tidak terlepas dari konstruksi teks serta mental dari pengalaman jurnalis terjadap ideologi gaya penulisan di HUPR.

Tentunya dalam hal ini HUPR memiliki nilai, pengaruh dan ideologi dari kehidupannya yang mempengaruhi dalam terbentuknya teks berita tersebut. Artinya, semua jurnalis di lingkungan HUPR memiliki gaya tulis, penguasaan bahasa, dan selingkung yang sama karena memang dikondisikan demikian. Keterbukaan informasi yang diberitakan oleh HUPR merupakan hasil dari refleksi sehari-hari yang terjadi di wilayah administrasi Jawa Barat, bisa berupa persoalan Hukum, Rekruitmen Pegawai, Politik, Birokrasi, dan berbagai hal yang secara langsung dijalani oleh masyarakat.

Kognisi sosial didasarkan pada anggapan umum yang tertanam dan digunakan pewarta untuk memandang peristiwa sebagai apa, dan bagaimana harus mengemasnya. Kemudian pewarta akan melakukan serangkaian penataan ide, ide ini secara alami menyesuaikan kebutuhan HUPR terkait isu tersebut. Pewarta harus mampu melakukan analisa untuk menjawab pertanyaan bagaimana peristiwa dipahami, dan dimengerti didasarkan pada skema. 
Skema jurnalis dihasilkan secara kolektif dari kebiasaan-kebiasaan yang tumbuh melalui interaksi antar jurnalis sesama HUPR, juga dibangun melalui arahan-arahan yang terus menerus digiatkan di lingkungan HUPR.

Lebih lanjut, kognisi sosial di HUPR bukan muncul pada orang perorang, melainkan dibentuk dan dilatih terus menerus oleh HUPR. Teun van Dijk menyebut skema ini sebagai model. Skema dikonseptualisasikan sebagai struktur mental dimana tercakup didalamnya bagaimana penulis memandang manusia, peranan sosial dan peristiwa itu sendiri. Skema ini akhirnya menuntun penulis untuk memahami, memaknai dan mengingat sesuatu.

Oleh karena itu, menurut van Dijk, analisis wacana harus menyertakan bagaimana reproduksi kepercayaan yang menjadi landasan bagaimana penulis menciptakan suatu teks tertentu. Dalam praktiknya, ada beberapa skema/model yang telah dijelaskan van Dijk, yaitu skema person, skema diri, skema peran dan skema peristiwa (Augoustinos, 1995: 36). Dari seluru skema tersebut yang akan berkontribusi dominan dalam membangun wacana pertama. Karena memang, di semua media massa, termasuk dengan HUPR, jurnalis atau wartawan merupakan bagian paling depan karena dari merekalah informasi diproduksi.

Keempat skema di atas turut dianalisis dalam penelitian ini untuk mengetahui bagaimana skema penulisan berita yang berpotensi membawa wacana keterbukaan informasi di Jawa Barat oleh HUPR. Juga atas kebutuhan data penelitian untuk menjelaskan pemahaman jurnalis dalam memahami peristiwa dan menyajikannya dalam berita keterbukaan informasi yang dipublikasikan melalui berita.

\section{Media: Masyarakat dan Kelas Counter Hegemoni}

Konsep hegemoni menjadi kajian populer setelah Antonio Gramsci membangun kesadaran pemikira politik modern. Ilmuwan politik Italia ini memberikan banyak argumentasi terkait adanya konsep kekuasaan. Anthonio Gramsci mengungkap tentang konsepsi negara dan hegemoni. Patria dan Arief (1999: 113-114) dalam paparannya menjelaskan konsep hegemoni dari Gramsci lahir untuk menjawab dua permasalahan utama. Yang mana persoalan itu terkait dengan proses penciptaan sebuah revolusi di Italia, sekaligus merupakan tantangan atas penafsiran Marxis setelah kematian Marx, Engels, Lenin dan Stalin. Persoalan yang mengemuka dari pertarungan hegemoni itu sendiri -sebelum mengurai kontribusi HUPR dalam membangun wacana hegemonistisnya-, setidaknya ada dua persoalan utama.

Pertama, mengapa terjadi kesenjangan antara idealisme media di HUPR dengan praktek politik yang justru mendominasi produksi teks atas media tersebut, dalam hal ini tentu HUPR. Dengan kata lain, HUPR berhasil membangun kelompok kelas pembaca dan menaruh ide hegemoninya melalui pemberitaannya. 
Konsep ini menurut Gramsci adalah penebaran ide atas kekuasaan melalui wacana teks. Sehingga pembaca HUPR tanpa sadar dikuasai melalui bahasa, dan keseluruhan proses produksinya.

Hanya saja, HUPR tidak membangun kelas penentang kekuasaan, justru kelas masyarakat yang dibangun oleh wacana HUPR merupakan kelas tengah yang tidak memiliki kekuatan apa-apa dalam melakukan gerakan kontrol, semisal mengawa jalannya pemerintahan, keterbukaan informasi yang memadai, dan hal lainnya. Sebagaimana inspirasi dari Marx, pengelompokan kelas merupakan upaya untuk mengakhiri kekuasaan kelas elit dalam sistem kapitalisme yang cukup matang.

Kedua, sarana dan strategi apakah yang dapat dilakukan untuk menutup kesenjangan tersebut, masyarakat dianggap hanya sebagai penerima kuasa, yang harus tunduk dan lemah, sedang penguasa bertindak sebagai kelas pengatur yang memiliki kontrol penuh. Dalam konteks krisis inilah sebenarnya pemikiran Gramsci tentang hegemoni lahir. Kemudian, dalam hal ini peneliti mencoba menjelaskan kekuasaan dalam membangun wacana oleh HUPR dari sudut pandang nalar Gramsci.

Mengutip dari argumentasi Robert Bocock (1986) dalam Patria dan Arief (1999: 116), di mana kekuatan hegemoni media seringkali bertalian dengan kekuasaan elit atau pemerintah. Meskipun secara ideal, pemerintah dan media massa seharusnya saling bertolak belakang, mengingat media haruslah berposisi sebagai kontrol kekuasaan (konter hegemoni).
Konsep hegemoni secara historis pertama kali diproduksi di Rusia pada tahun 1880 oleh seorang Marxis Rusia, Plekanov. Konsep ini dibangunnya sebagai bagian dari strategi untuk menjatuhkan pemerintahan Tsar. Hegemoni dalam definisi ini mengacu pada pengertian kepemimpinan hegemonic-ploretariat serta perwakilan-perwakilan politik mereka serta aliansi-aliansi dengan kelompok lain seperti kaum borjuis kritis, petani dan intelektual yang berkeinginan sama untuk menjatuhkan pemerintahan Tsar.

Konsep hegemoni Gramsci (2001: 57-58) sebenarnya dapat dirunut melalui penjelasannya tentang Basis dari Supremasi Kelas, di mana supremasi kelompok di masyarakat menunjukkan eksistensinya melalui dua cara, yakni lewat dominasi (dominance) dan kepemimpinan intelektual(direction).

Melihat perkembangan pemberitaan HUPR, wilayah dominan ini dikemas melalui ideologi jalan tengah, yang mana HUPR memilih untuk menciptakan keheningan, ketenangan, meskipun harus mengorbankan kebenaran yang berpihak pada khalayak ramai. Artinya, HUPR tidak memposisikan diri sebagai media yang harus melakukan kontrol, melainkan menetapkan diri sebagai penyambung informasi semata, tidak lebih dari itu. Kemudian, pada tataran direction, adalah kekuasaan narasumber yang lebih sering memihak pada kekuasaan pemerintah dan HUPR hanya menerima informasi kuasa itu apa adanya, tanpa melakukan superfisi dengan menghadirkan narasumber penyeimbang. 
Jika analoginya adalah kekuasaan konvensional, maka marxis memberikan penjelasan sebagai berikut. Kedua kelompok ini akan terus-menerus saling menundukkan. Biasanya kelompok sosial yang satu mendominasi kelompok-kelompok oposisi lewat berbagai cara, termasuk kekuatan senjata untuk melumpuhkannya. Di satu sisi, kelompok-kelompok sosial yang dipimpin oleh para intelek akan berusaha melawan dominasi rezim lewat mobilisasi kelompok kerabat, mahasiswa dan stake holder basis masyarakat lainnya. Gramsci mengisyaratkan satu hegemoni bisa hancur dan digantikan oleh kelompok sosial lainnya yang memiliki posisi yang dominan, sehingga menghasilkan rezim baru (rulling elite).

Penjelasan Gramsci tentang supremasi kelas, menunjukkan suatu totalitas yang didukung oleh kesatuan dua konsep yakni direction dan dominance. Hubungan kedua konsep ini menyiratkan tiga hal yakni: Pertama, dominasi dijalankan atas seluruh musuh dan kepemimpinan dilakukan kepada segenap sekutu. Kedua, kepemimpinan adalah suatu prakondisi untuk menundukkan aparatus negara (kekuasaan pemerintahan). Ketiga, sekali kekuasaan negara bisa direnggut, dua aspek supremasi kelas ini baik pengarahan ataupun dominasi akan terus berlanjut.

Analisis Gramsci di atas berusaha memberikan penjelasan bahwa sebenarnya semua kelas sosial di masyarakat memiliki kecenderungan untuk menghegemoni, ketika memiliki kemampuan untuk mendominasi.
Dominasi adalah kunci awal dalam proses hegemoni. Di antara sekian potensi dominasi, negara adalah institusi yang paling kuat dalam hal dominasi, sehingga wajar apabila negara memiliki kecenderungan tinggi untuk menghegemoni masyarakatnya.

Dalam konteks pengakuan dirinya sebagai seorang revolusioner yang tugasnya menciptakan revolusi sebagai suatu alternatif strategi bagi "kemegahan" perjuangan sosialis, khususnya Italia dan Eropa umumnya, maka Gramsci sebagaimana dikutip oleh Hendarto (1993: 82-84) mengemukakan tiga tingkatan hegemoni yaitu: Pertama, hegemoni integral, yakni hegemoni yang ditandai dengan afiliasi massa yang mendekati totalitas. Kedua, hegemoni yang merosot (decadent hegemony), yakni kemerosotan yang disebabkan oleh lemahnya "mentalitas" massa yang tidak sungguh-sungguh selaras dengan pemikiran yang dominan dari subjek hegemoni. Ketiga, hegemoni minimum (minimal hegemony), merupakan bentuk hegemoni yang paling rendah, dibanding dua bentuk di atas.

\section{SIMPULAN}

wacana kritis ini mengungkap bahwa HUPR menjalankan praktik diskursus modernitas, yakni wacana secara sistem yang diarahkan oleh HUPR sebagai kelompok kapitalis kepada totalitarianisme birokratis (pemerintah) demi kepentingan akumulasi modal. 
Birokrasi pasti menutup rapat akses publik terhadap berbagai praktek yang seharusnya terjadi di dalamnya.

Informasi merupakan alat yang akan mengantarkan pada diskursus publik dan melakukan penilaian terhadap berbagai unsur yang ada dalam informasi. Peniadaan informasi berarti peniadaan terhadap diskursus dan wacana publik terhadap berjalannya satu kesepakatan sistem. Konteks itulah kekuasaan dan penguatan akumulasi modal di dalamnya. Sistem yang tertutup merupakan ajang konspirasi dan penyalahgunaan kekuasaan satu rezim.

\section{REFERENSI}

Ahba, Reawan. (1995). Media and Thinking Humanity. Singapore: Singapore University Press

Albrow, Martin. (1998) Birokrasi. M. Rusli Karim dan Totok Daryanto (pen). Yogyakarta: Tiara Wacana

Alfian dan Syamsuddin, Nazaruddin (ed). (1991) Profil Budaya Politik Indonesia. Jakarta: Pustaka Utama Grafiti.

Allen, V.L. (1995). Power in Trade Union. London: Longman

Antony. (2004). Riuhnya Persimpangan Itu: Seri Komunikasi. Solo: Tiga Serangkai

Arifin, Anwar. (2011). Komunikasi Politik. Yogyakarta: Graha Ilmu

Arikunto, Suharsimi. (1998) Prosedur Penelitian Suatu Pendekatan Praktek. Jakarta: Rineka Cipta.
Arnhart, Larry. (1987) Poitical Questions: Political Philosophy Plato to Rawls. New York: Macmillan Publishing Company

Badara, M. S. (2015) Empirical Evidence of Performance Measurement of Internal Analysis Function onits Effectiveness. Academic Journal of Management Science Research, 1 (1), 1- 10

Badara, M. S. (2015) Empirical Evidence of Performance Measurement of Internal Analysis Function onits Effectiveness. Academic Journal of Management Science Research, 1 (1), 1- 10

Bagdikian, Ben. (2003). The Media Monopoly. New York: Longman

Baran, Stanley J. (2004) Introduction to Mass Communication; Media literacy and Culture. New York: McGraw Hill

Barker, Chris. (2005) Cultural Studies. Teori dan Praktik. Jakarta: Tiara Wacana

Baudrillard, Jean. (1998). The Consumer Society. London: Sage Publication

Baudrillard, Jean. (1978). The Simulacra. New York: McComb Publishing

Bigogiari, D. (1953). The Political Ideas of St. Thomas Aquinas. New York: Hafner

Blau, Peter M., dan Meyer Marshall. (2000). Birokrasi Dalam Masyarakat Modern. Penterjemah: Slamet Rijanto. Jakarta: Prestasi Pustakaraya

Bungin, M. Burhan. (2007) Sosiologi Komunikasi. Jakarta: Prenada Media

Castells, Manuel. (2001). The Power of Identity. Oxford: Blackwell

Castells, Manuel. (2001) The Rise of The Network Society. Oxford: Blackwell 
Castells, Manuel. (2001) The Rise of The Network Society. Oxford: Blackwell

Compton, Boyd R. (1992). Kemelut Demokrasi Liberal. Jakarta: LP3ES

Crowley, David. and David Michell.(1994). Communication Theory Today. Kota: Polity Press

Dahlgren, Peter. (2000). Teory, Boundaries and Political Communication. London: Sage Publishing 